Marquette University

e-Publications@Marquette

Theology Faculty Research and Publications

Theology, Department of

$1-1-2013$

Functional Specialties for a World Theology

Robert M. Doran

Marquette University, robert.doran@marquette.edu

Published version. Lonergan Workshop, Vol. 24 (2013): 99-111. Publisher Link. (C) 2013 Lonergan Institute at Boston College. Used with permission. 


\title{
FUNCTIONAL SPECIALTIES FOR A WORLD THEOLOGY
}

\author{
Robert M. Doran, S.J. \\ Marquette University \\ Milwankee, Wisconsin
}

IN THIS PAPER I WISH to make a suggestion regarding the significance of Bernard Lonergan's breakthrough to functional specialization, a significance that has to do with the future of Catholic theology in the world church that Karl Rahner correctly says was mediated into thematic self-recognition at the Second Vatican Council. My suggestion is at once theological and methodological. The theological ground of the hypothesis is the doctrine of the universal mission of the Holy Spirit. The methodological component is Bernard Lonergan's notion of functional specialization. The significance of Rahner's vision of the Second Vatican Council for functional specialization is, I believe, that the eight functional specialties are to be applied by Catholic theology to the universal religious situation of humankind.

More radically, the methodological component in this proposal is the invariant structure of intentional consciousness that, when complicated, becomes, among other things, functional specialization. ${ }^{1}$

1 "Similarly, the second chapter, on functional specialties, was a complication of the basic structure. We have the four levels (experiencing, understanding, judging, deciding) occurring in two phases; and the effort concentrates on the end of the first level, the second level, the third level, and the fourth level. This happens twice and so you get eight. It's a complication of the basic structure. As presented, it was a complication of the basic structure...something similar will be required whenever you have an academic discipline that deals with man's past with a relevance to his future." Bernard Lonergan, Early Works on Theological Method 1, vol. 22 of the Collected Works of Bernard Lonergan, ed. Robert M. Doran and Robert C. Croken (Toronto: University of Toronto Press, 2010) 478-79. (The chapter on functional specialties was at the time - 1968 - projected to be chapter 2 in Method in Theology. The occasion of the cited comment was the set of lectures that Lonergan delivered at Boston College in 1968, where, to my knowledge, he first went public with the notion of functional specialization.) 
This methodological component meets the theological ground, the gift of the Holy Spirit, when it is acknowledged that the gift of God's love is the supernatural fulfilment of the obediential potency of nature, that is, intentional consciousness as a principle of movement and rest in search of true meanings and a normative and nuanced scale of values. ${ }^{2}$ When the two meet, there is achieved the foundation for an integration of religious studies and theology, a major fruit of what Lonergan called the ongoing genesis of methods. ${ }^{3}$

I presume familiarity with the methodological component. While there are still needed clarifications regarding intentional consciousness, ${ }^{4}$ the judgment that the structure is not subject to radical revision is common currency among Lonergan students. But the debate surrounding the theological component rages on - perhaps much to the consternation of the Holy Spirit herself, who I suspect might like us to gain greater clarity and agreement in her regard.

I would like to locate this presentation within a larger ongoing context. That context is partly located in a public discussion that began in October 2009 at Marquette University. I hope this discussion will continue over the years at Marquette, in an annual colloquium on "Doing Catholic Theology in a Multi-religious World." My hope for the colloquium is that, after some years of debate and discussion, we will have arrived at the broad outlines of a genuinely Catholic theology of religions. At the first of these colloquia, which are sponsored by the

$2 \mathrm{My}$ understanding of the relation of nature and grace is based on Lonergan, not on Rahner. See Jeremy Blackwood, "Lonergan and Rahner on the Natural Desire to See God," METHOD: Journal of Lonergan Studies, new series, 1, no. 2 (2010): 85-103. Like functional specialization, the scale of values is a complication of the structure of intentional consciousness elevated by divine grace, one that opens on the collective responsibility that is made operative as grace takes on social and cultural effectiveness. See Robert M. Doran, "Social Grace," paper delivered at the 2010 West Coast Methods Institute, Loyola Marymount University, now published in METHOD: Journal of Lonergan Studies, new series 2, no. 2 (2011): 131-42.

3 See Bernard Lonergan, "The Ongoing Genesis of Methods," in A Third Collection, ed. Frederick E. Crowe (Mahwah, NJ: Paulist Press, 1985): 146-65.

4 The clarifications would regard primarily the first and the fourth "levels" in the structure. For my own suggestions, see, regarding the first "level," Robert M. Doran, "Reception and Elemental Meaning," Toronto Journal of Theology 20 (2004): 133-57, and, regarding the fourth, Robert M. Doran, "Ignatian Themes in the Thought of Bernard Lonergan: Revisiting a Topic that Deserves Further Reflection," Lonergan Workshop 19, ed. Fred Lawrence (Boston College, 2006): 83-106. 
Marquette Lonergan Project, papers by John Dadosky, Darren Dias, and myself emphasized the universal mission of the Holy Spirit, and so the theological component of my present hypothesis, as a central locus of twenty-first-century Catholic systematics. The papers stressed Frederick Crowe's position on the relations of the missions of the Holy Spirit and of the Son, ${ }^{5}$ and brought into play and updated with Lonergan's help some central Ignatian insights regarding discernment and dialogue. ${ }^{6}$

The upshot of the first colloquium was twofold: a shared recognition, acknowledged from the beginning by the speakers but definitely heightened in the course of the discussion, of the need for greater clarity regarding the mission of the Son in relation to that of the Holy Spirit, but also a tacit agreement, it would seem, with a statement in my paper to the effect that the global implications of the scale of values would provide an extraordinary litmus test regarding the major authenticity of the various religious traditions in our world, where "major authenticity" refers not to the authenticity of individuals vis-àvis their traditions but to the authenticity of the traditions themselves as currently appropriated and implemented or exercised. These two results of the first colloquium became the starting point for the second, which was held in early November 2010. In my own presentation for that colloquium, I related the two results to one another, by attempting to specify the relation between the mission of the Word, understood in terms of incarnate and linguistic meaning, and the cultural and social manifestations of the mission of the Spirit in the gift of God's love. ${ }^{7}$ But in the present paper, I want to specify further the implications of the position that I am taking regarding the mission itself of the Holy Spirit, and I want to indicate what I think these implications mean for our very notion of theology and especially for the notion of a Catholic theology explicitly structured by functional specialties.

5 Crowe's principal paper on the topic is "Son of God, Holy Spirit, and World Religions," presented as the Chancellor's Lecture at the Regis College Convocation, Toronto, November 26, 1984. Published in 1985 by Regis, and in Appropriating the Lonergan Idea, ed. Michael Vertin (Toronto: University of Toronto Press, 1989), 324-43.

6 The three papers can be found in PDF and audio on the new website www. lonerganresource.com, under Events: Conferences: October 29-30, 2009.

7 See Robert M. Doran, "Social Grace and the Mission of the Word," on www. lonerganresource.com, under Events: Conferences: November 4-5, 2010. 
I will begin with a short section on the mission of the Holy Spirit, where I rely more on Crowe's position than is clear from what I have time to say here. In fact, if Crowe's position is not correct, then what I am proposing regarding functional specialties for a world theology needs to be rethought. The position proposed here depends on Crowe's theological doctrine regarding the mission of the Holy Spirit in relation to that of the Son. In a second section, I will offer my own position on the structure of the gift of the Holy Spirit, repeating in summary form the major points of my paper at the Lonergan Workshop in 2009. I will conclude with a proposal regarding the implications of these positions for a methodical theology, that is, for a collaborative effort structured by functional specialization.

\section{THE MISSION OF THE SPIRIT}

The Holy Spirit is God's first gift. The Holy Spirit is, first and foremost, the gift that the Father and the Son give to each other as together they communicate the divine nature to the relation of love that unites them. But the divine missions are the divine processions linked to a created, contingent, and consequent term. The gift of the Holy Spirit mutually uniting the Father and the Son is historicized and universalized, and recognition of this establishment of the so-called economic Trinity yields the theological and, I dare say, ecclesial doctrine that everyone is offered the gift of the divine favor and its transforming power, irrespective of all contingent circumstances, including religious affiliation. The doctrine of the universal salvific will of God means that wherever there has been the obediential potency that is human attentiveness, intelligence, rationality, and moral responsibility, there has been the offer of the gift of God's love, that is, the gift of the Holy Spirit. Then, in the fullness of the Holy Spirit's time, the Father sent the Son, who was conceived by the Holy Spirit in the womb of the Virgin Mary, driven by the same Spirit into the desert for forty days, led back by the Spirit to preach the coming of God's reign, and raised to life from death by the Father in the power of the Holy Spirit. In other words, the mission of the Holy Spirit is not only intensified but also revealed, made thematic, in the mission of the Son, where it plays a constitutive role. That Holy Spirit was then sent by the Father and the Son on the apostles and the 
other women and men gathered in the upper room on Pentecost. This sending was to fulfill the twofold mission of the Son and the Spirit and to acknowledge that what happened in Jesus was indeed the revelation of what the triune God has always been doing in human history. The time since then, the celebration of which in the liturgical cycle we call "ordinary time," is really, as Fred Crowe loved to say, the time of the Holy Spirit. It is the ongoing fifth act in the drama of salvation as the latter is conceived by Raymund Schwager, an act in which we are all among the principal protagonists. ${ }^{8}$ The mission of the Word is, among other things, the explicit revelation through linguistic and incarnate meaning of what God has always been doing and continues to do in the inner word of the mission of the Holy Spirit, namely, pour out divine love upon us. That is the good news. "God loved the world so much that he gave his only Son" (John 3:16). The move that Frederick Crowe makes in the paper on which so many of us have come to rely is that we share a religious community with all human beings, including the people of the world's religions, a community grounded both in the common orientation of nature through intentional consciousness to the mystery of love and awe that in fact is the transcendent triune God and in the universal gift of the transcendent God's triune life through what Christians would confess to be the indwelling Holy Spirit. I cannot elaborate further on Crowe's rich paper here, but I suspect that many of you are already familiar enough with its basic thesis that I can move on with my own argument. Pneumatology will, I believe, be the most important area of serious systematic theology in this century, and I hope and believe that Crowe's position, which most likely is also Lonergan's, will become part of the foundation of a twenty-first-century pneumatology.

8 See Raymund Schwager, Jesus in the Drama of Salvation: Toward a Biblical Doctrine of Redemption, trans. James G. Williams and Paul Haddon (New York: Crossroad, 1999). The five acts are: (1) Jesus' preaching of the reign of God, (2) the conflict with the religious authorities because of his preaching of the reign of God, (3) the crucifixion and death of Jesus, (4) the resurrection of Jesus from the dead, and (5) the gift of the Holy Spirit at Pentecost. The latter I am conceiving not as the first and original gift of the Holy Spirit to humankind, which is a universal reality, but as the special confirmation by the Holy Spirit that the mission of the Word was indeed the genuine revelation of what God has been doing all along in the universal gift of the Spirit. 


\section{THE GIFT OF THE HOLY SPIRIT}

Ever since writing and publishing the controversial article "Consciousness and Grace," I have been working at further clarification regarding the immanent constitution of our life in God. The position that I have arrived at, largely by laboring over Lonergan's 1951-52 notes on sanctifying grace, is remarkably similar to the one I proposed in "Consciousness and Grace." The present articulation of my position goes as follows (in brief compass).

There is an uncreated gift given to us by the Father, a gift whom Christians name the Holy Spirit. The gift, as uncreated, is constituted by God alone. By the gift the triune God assumes a constitutive role in our living, not as an inherent form or quasi-form, as Karl Rahner might say, but as the term of a set of created relations. The human subject of the first of those relations, the relation to the Holy Spirit, is the central form, the soul, the core of identity, of a subject elevated by sanctifying grace. The term of that created relation is the uncreated Holy Spirit.

This divine self-communication, constituted by God alone, really allows each of the persons of the Trinity to be present to those to whom the created grace of God's favor (gratia gratum faciens) has been given. The major point in my position lies in an attempt to understand how this can be, how the gift of the Holy Spirit as the uncreated term of a created relation allows the other persons of the Trinity to be present as distinct terms of a distinct created relation. I hold that it is specific and peculiar to Christianity that it makes this set of interpersonal relations, which are always given by God, explicit; it elevates them from the vécu to the thematique. But that is doctrine, and the difficult point is not the doctrine but understanding it. The doctrine is given explicitly in scripture, at least in the Gospel of John. But how it is to be understood has been the subject of nearly endless debate, and while I have attempted to express an understanding that I believe works, I am not sanguine enough or foolish enough to believe that it puts an end to the disputes.

The created gift by which God draws us into participation in

9 Robert M. Doran, “Consciousness and Grace," METHOD: Journal of Lonergan Studies 11, no. 1 (1993): 51-75. This paper is now available online with new notes, as the first of a set of "Essays in Systematic Theology" on the website www.lonerganresource.com, under 'Scholarly Works: Books: Robert M. Doran, Essays in Systematic Theology:An E-book. 
divine life, and by which it is true that the Holy Spirit is given to us and dwells in us as the term of a created relation, is to be conceived as effected, created, by the love that is common to the three divine persons; but it is also to be conceived as immanently constituted in terms of created participations in what Aquinas calls the "notional acts" proper to each of the divine persons. While sanctifying grace is effected by the love common to the three divine persons, it establishes in us distinct relations to each of them and a distinct participation in the divine life of each of them, in keeping with the distinct fashion in which each of them exercises the divine creative love. The question for systematics is, How can this be?

The first of these created relations we have already seen, the created relation to the uncreated Holy Spirit. This is the fundamental divine gift, the gift to us of the same Holy Spirit whom the Father and the Son give to one another eternally. But the affirmation that the Holy Spirit is sent to us can be true only if there is a created condition consequent on the mission by which it is possible to affirm the mission itself. That created consequent condition is the elevation of the central form, the "I," of the human being to a participation in divine life that makes possible a created relation to the uncreated Holy Spirit. The subject of that relation is the elevated central form, substantial form, soul. As a created relation to the Holy Spirit, this relation imitates and participates in the uncreated relation to the Holy Spirit that the Father and the Son are. That is, it imitates and participates in what the psychological analogy has traditionally called active spiration. Thus the created gift called sanctifying grace, which is nothing other than the reception of actively spirating love as it elevates central form to a created supernatural relation to the uncreated Holy Spirit, is a created participation in the Father and the Son together actively "breathing" the Holy Spirit. It is experienced, at least as recollected and made thematic in memory, as being on the receiving end of unconditional love. We have been given a share in the relation to the Holy Spirit that in God is the Father and the Son actively loving each other and in that loving "breathing," "spirating," the Holy Spirit. In this active loving, the Father communicates divine love to the Son, who responds precisely as Verbum spirans Amorem, an eternal Judgment of Value that breathes eternal love, the proceeding love that is the Holy Spirit 
issuing as the mutual love of the Father and the Son. Because of the participation in the Verbum spirans Amorem, the change in us entails a created judgment of value or, better, set of judgments of value, from which there proceeds the created love that shares in the Proceeding Love that is the Holy Spirit. This created love is the love that we call charity. Charity relates us back to the Father and the Son in a created participation in the passive spiration of the Holy Spirit, setting up an inverse created relation to the uncreated Father and Son, who also dwell in us as terms of a created relation.

Aquinas and the early Lonergan thus distinguish charity from sanctifying grace. That distinction is based in the Aristotelian metaphysics of substance and accidents, where the soul is substantial form and the will is a conjugate faculty of the soul. Sanctifying grace is an entitative habit rooted in the soul while charity is an accidental or conjugate habit emanating in the will. I remain convinced that there is a validity to this metaphysics, that it is not to be jettisoned but transposed, and that the solution to the problem with which I am concerned lies in effecting an appropriate transposition of that metaphysics into the terms and relations of a religiously differentiated consciousness informed by Christian revelation.

In that transposition, charity, as a created participation in and imitation of the Holy Spirit, sets up an inverse created relation to the Father and the Son, who thus are also present to us, dwelling in us, as terms of a created relation. The biblical doctrine of the indwelling of all three divine persons is transposed by a technical systematic theology into the affirmation of the indwelling of all three divine persons as terms of distinct relations. The further "interiority" transposition of "the habit of charity" would be captured in an affirmative response to the fourth form of the question of God, as this is expressed on page 116 of Method in Theology: “...now it is primarily a question of decision. Will I love [God] in return, or will I refuse? Will I live out the gift of [divine] love, or will I hold back, turn away, withdraw?" In this transposition, the gift that a metaphysical theology called sanctifying grace is the gift of divine love, of the grace that makes us pleasing to God in the special way that indicates God's desire that we be God's friends, and so that establishes a created relation to the uncreated Holy Spirit; it is God's being in love with us; and charity is the reciprocal dynamic state of our 
being in love with God. Sanctifying grace is "gratia operans," and charity "gratia cooperans" in the realm of habitual grace. Interestingly enough, the recently published volume 22 in the Collected Works of Bernard Lonergan reveals that as late as the 1968 institute at Boston College, Lonergan identified "being in love with God," not with sanctifying grace, as in Method in Theology, but with charity. This is part of the position that I defended in "Consciousness and Grace," and I would suggest that we return to it. Lonergan later admitted in a discussion session at a Lonergan Workshop in 1974 that in Method in Theology he had amalgamated sanctifying grace and charity. ${ }^{10}$ It has been my position since I wrote "Consciousness and Grace" that that amalgamation was a step back from religious differentiation, and that we should return to the distinction between sanctifying grace and charity affirmed by Aquinas and by the early Lonergan, and work at further refining the interiority transposition of that distinction. In fact, I think, that distinction will give us the "special basic relations" that, strangely, are not mentioned in the basic methodological position expressed on page 343 of Method in Theology: “...the basic terms and relations of systematic theology will be not metaphysical, as in medieval theology, but psychological...general basic terms name conscious and intentional operations. General basic relations name elements in the dynamic structure linking operations and generating states. Special basic terms name God's gift of his love and Christian witness. Derived terms and relations name the objects known in operations and correlative to states." Special basic relations would be the relations between receiving the favor of God and living out the gift of divine love by loving God in return.

I have spoken also of a set of judgments of value that proceeds from the reception of the gift of God's love. I would like to propose that this set of judgments of value constitutes the universalist "faith" that Lonergan distinguishes in his later work from the beliefs of particular religious traditions. If this is the case, the judgments of value are crucial to any attempt to build a Catholic systematic theology of religions. The faith reflected in such judgments of value can be and is found in diverse traditions, and is responsible, it would seem, for Lonergan's hope that

10 This comment occurs in the last of the question-and-answer sessions in the 1974 Workshop. The recording of this session is now available as $81500 \mathrm{A0E} 070$ on the website www.bernardlonergan.com, with a corresponding transcription at 81500DTE070. 
the religions of the world will find common ground and common cause in the gift of God's love. Such faith is "the knowledge born of religious love," ${ }^{11}$ a knowledge contained in judgments of value consequent upon the reception of the gift of unqualified love. This knowledge called faith grounds the proceeding charity that is our created participation in the passive spiration that is the Holy Spirit.

Thus the analogy that I suggest starts with the reception of the gift of God's love, recollected in memory and grasped as sufficient condition for there to proceed a set of judgments of value; from these two there flows the charity that is the love of God in return. What makes this analogy different from those proposed by Augustine, Thomas, and both the early and the later Lonergan is not its structure, which is identical in all of these analogies, but rather the fact that it is explicitly an analogy, not from nature to the supernatural order, but within the supernatural order itself. Created grace has a Trinitarian form. The analogy in the order of grace begins with the gift of God's love, retrospectively interpreted as a gift of being on the receiving end of a love that is without qualification and that has about it something that seems to emanate from the foundation of the universe. The initial step in the analogy is composed of the gift of God's love recollected and acknowledged in memory. This step, grasped as grounding an assent, issues in the inner word of a judgment of value proceeding from memory and acknowledging the goodness of the gift. This judgment of value is the foundation of a universalist faith that is present in all authentic religion. The recollection and judgment of value together constitute a created share in, participation in, imitation of, divine active spiration, the active loving of the Father and the Son for each other from which divine Amor procedens, passive spiration, the Holy Spirit, originates. Memoria and its verbum spirans amorem give rise to the disposition of charity, the antecedent universal willingness that is a created participation in and imitation of the Holy Spirit, a disposition that establishes a reverse relation of love for the Father and the Son. The relation between the love acknowledged in memoria and its word, on the one hand, and charity on the other, is analogous

11 Method in Theology, 115. For Lonergan's understanding of this universalist faith and its distinction from the religious beliefs of particular traditions, see Method in Theology, 115-19. 
to the relation between active and passive spiration in the triune God. The three divine persons dwell in us and among us, are present to us, precisely as the uncreated terms of two created supernatural relations: supernatural, because their term is God as God is in God's threefold conscious self, which is beyond the proportion of any created nature and so absolutely supernatural. And all of what I have just said constitutes a twofold transposition - theoretical and methodological - of the very movement of the Spiritual Exercises of St Ignatius: from the reception of divine love at the beginning to the "Contemplation for Attaining Love of God" in return at the very end. That contemplation contains the basic structure that I am suggesting: memory recollecting and making thematic the gift that one has received, the judgment of value that this is indeed very good, and the awakening of love for the One who has first loved us. Memory and judgment of value together are a created share in active spiration, and the awakening of love in return is a created participation in passive spiration.

\section{FUNCTIONAL SPECIALITIES FOR A WORLD THEOLOGY}

Finally, and all too briefly, I come to the main distinguishing point of this particular presentation.

Lonergan says in Method in Theology that the correct answer to the question, What data are relevant to Christian theology? occurs, not in the functional specialty concerned with the data themselves, that is, research, but in the sixth functional specialty, the one concerned with doctrines. But, he goes on to ask, "How can the sixth specialty be reached, if one does not know which are the areas relevant to theological research, and how each area is to be weighted?" His answer is typical: "...let Christian theologians begin from where they already stand. Each will consider one or more areas relevant to theological research. Let him work there. He will find that the method is designed to take care of the matter." 12

Now, my question is, What happens with respect to the question of the areas relevant to theological research if a Christian theologian stands on Frederick Crowe's theological doctrine. regarding the relation of the mission of the Holy Spirit to the mission of the Son?

12 Method in Theology, 150. 
What happens if such a theologian affirms that we Christians share a religious community with all human beings, including the people of the world's religions, precisely because the divine person whom we call the Holy Spirit has been sent to all; again, precisely because the created participations in Trinitarian active and passive spiration that Christian theologians are enabled to make thematic are in fact a universal offer on the part of the triune God to all women and men at every time and place in human history, whether that offer be vécu or thématique?

What happens is that the relevant data for Christian theology are magnified exponentially; and the consequences for the other functional specialties in the first phase of theology are enormous in their implications. For all the data on human religious living, whether that living be explicit or compact, are now to be made available for Christian theology itself; they are to be interpreted in accord with the hermeneutic theory presented in both chapter 17 of Insight and chapter 7 of Method; and the relevant history for Christian theology itself expands to include the religious history of all of humanity. That such a proposal does not mean the collapse of theology into positivist religious studies is guaranteed by accepting the functional specialization of theological tasks; for then, beyond research, interpretation, and history, which is where religious studies would stop, there remains, in the first phase, the dialectic that would mediate the differences, and then there is the normative subject, the concrete universal moving the whole of theology to a second phase; and in that second phase there will emerge vastly expanded functional specialties of foundations, doctrines, systematics, and communications. The result will be a vast collaboration constructing what we may call a world theology or a theology for a world church, a theology that takes its stand on the theological and ecclesial doctrine of the universal mission and gift of the Holy Spirit, and that applies the methodological doctrine of functional specialization to the task of mediating from data to results an entire worldwide community of men and women receiving and responding to what Christians know as the third divine Person, the Holy Spirit of God, proceeding Love in the Trinity poured out in the hearts of all by the gift of the triune God to all. The content of all eight functional specialties is expanded vastly if we take our stand on Crowe's theological doctrine. 
Such is the vision, in very brief compass. I do not have the time to pursue it further here. But I know I cannot consider the work that I'm currently doing on The Trinity in History complete even in a first installment until this vision has been explored and mined further. But I must stop here at present. ${ }^{13}$

13 Since I delivered this paper at the 2010 Lonergan Workshop, there have been two developments in my thinking relevant to the problems treated here. In "Social Grace and the Mission of the Word," the universalist faith mentioned above is affirmed to be a participation in an invisible mission of the divine Word. And in a paper published in METHOD: Journal of Lonergan Studies, (new series 2, no. 1 [2010]: 13-16), "The Ninth Functional Specialty," the objectification of the normative subject is removed from the functional specialty Foundations to become a ninth functional specialty, Horizons, mediating between the first and second phases of theology. What is left in the place of Foundations in Lonergan's schema of the functional specialties I now call Categories. 